\title{
Accumulation and tolerance to cadmium, copper, lead and zinc by the green mussel Perna viridis
}

\author{
H. M. Chan* \\ Department of Zoology, University of Hong Kong, Pokfulam Road, Hong Kong
}

\begin{abstract}
The green mussel Perna viridis (Bivalvia: Mytilacea) was exposed to a range of dissolved concentrations of $\mathrm{Cd}, \mathrm{Cu}, \mathrm{Pb}$ and $\mathrm{Zn}$ for $21 \mathrm{~d}$. Accumulation of $\mathrm{Zn}$ has been interpreted in terms of a regulation mechanism to maintain constant body concentrations at ca $100 \mu \mathrm{g} \mathrm{Zn} \mathrm{g}{ }^{-1}$ dry wt at external

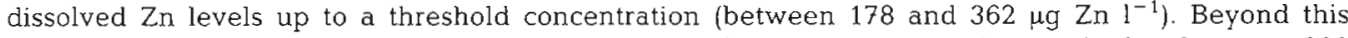
threshold, net accumulation of body Zn continued until body Zn concentration reached a plateau at 200 $\mu \mathrm{g} \mathrm{g}^{-1}$ Cadmium, $\mathrm{Cu}$ and $\mathrm{Pb}$ were linearly accumulated by $P$. viridis in proportion to ambient metal concentrations over $7 \mathrm{~d}$. Toxicity of $\mathrm{Cd}, \mathrm{Cu}, \mathrm{Pb}$ and $\mathrm{Zn}$ was evaluated in $96 \mathrm{~h}$ bioassays; LC-50 values in $\mu \mathrm{g}^{-1}$ were 620 for $\mathrm{Cu}, 1570$ for $\mathrm{Cd}, 6090$ for $\mathrm{Zn}$, and 8820 for $\mathrm{Pb}$.
\end{abstract}

\section{INTRODUCTION}

Marine invertebrates accumulate trace metals to varying degrees, and body concentrations may reach high levels (e.g. Bryan 1979, Prosi 1979). Marine invertebrates, especially molluscs, therefore have been used widely as monitors of trace metal pollution (Phillips 1977, 1980, Bryan at al. 1980, 1985), concentrations of metals in whole or parts of these organisms being taken as measures of ambient concentration Most of these studies assume that a simple linear relation exists between metal concentration in water and in marine organisms. This may not necessarily be true. The net accumulation of any metals taken up will depend for example on the relative rates on metal excretion and storage of metal in detoxified form.

It is, therefore, inappropriate to assume that a given species will accurately reflect the ambient concentrations of pollutants in its environment without regulating the amounts accumulated. Phillips \& Segar (1986) concluded that laboratory and field studies are required to prove the indicator ability of any untried species. Consequently, the aim of the present study was to examine the pattern of accumulation of essential ( $\mathrm{Cu}$ and $\mathrm{Zn}$ ) and non-essential (Pb and $\mathrm{Cd}$ ) trace metals by the green-mussel Perna viridis (Bivalvia: Mytilacea). Additionally, short-term toxic effects of metals on $P$. viridis have also been evaluated.

\footnotetext{
- Present address: School of Biological Sciences, Queen Mary College, University of London, Mile End Road, London E1 4NS, United Kingdom
}

\section{MATERIALS AND METHODS}

Perna viridis were collected by subaqua diving from a sublittoral population at Ma Liu Shui, Tolo Harbour, Hong Kong in November 1986. They were maintained in a laboratory seawater aquarium at $20^{\circ} \mathrm{C}$ and $33 \mathrm{ppt}$ salinity for at least 1 mo and used as stock for all subsequent experiments.

Experiment I: Accumulation and regulation. Prior to metal exposure, mussels were acclimatized in artificial seawater (HW Marinemix, Wiegandt GMBH \& Co., F. R. Germany) for 5 d. Groups of 20 mussels (of 55 to $65 \mathrm{~mm}$ shell length) were selected in order to minimize effects caused by size differences. Artificial seawater was chosen as exposure medium since it represents a medium easier to reproduce than natural seawater, particularly with respect to dissolved organic matter which might chelate added metals. Moreover, artificial seawater prepared with freshly distilled water was confirmed to contain lower concentrations of $\mathrm{Cd}, \mathrm{Cu}, \mathrm{Pb}$ and $Z n$ than natural seawater.

Each group of 20 Perna viridis was exposed for $21 \mathrm{~d}$ to one of a number of metal concentrations in $5 \mathrm{l}$ artificial seawater of $33 \mathrm{ppt}$ salinity at $20^{\circ} \mathrm{C} \pm 2{ }^{\circ} \mathrm{C}$ under a 12:12 h light:dark regime in acid-washed $10 \mathrm{l}$ perspex tanks with continuous aeration. The mussels were not fed during the experiments.

Media were changed twice weekly, and dissolved metal levels were monitored periodically by chelationsolvent extraction and flame atomic absorption spectrometry (Kremling \& Peterson 1974, Bone \& Hibbert 1979). Analyses confirmed that under these conditions 
the concentrations of dissolved $\mathrm{Cd}, \mathrm{Cu}, \mathrm{Pb}$ and $\mathrm{Zn}$ remained within $10 \%$ of the declared values. The artificial seawater used was found to contain inherent levels of $3.1,11.0,6.0$ and $0.7 \mu \mathrm{g} \mathrm{l^{-1 }} \mathrm{Cu}, \mathrm{Zn}, \mathrm{Pb}$ and $\mathrm{Cd}$ respectively. Additional metals were added as required from standard stock solutions of the metal (1000 $\mathrm{g} \mathrm{l}^{-1}$ ), either as sulphate ( $\mathrm{Cu}$ and $\mathrm{Zn}$ ) or chloride ( $\mathrm{Pb}$ and $\mathrm{Cd}$ ) (Analar grade, BDH, UK). Salinity changes were minute but were nevertheless equalized in all experimental tanks by addition of similar aliquots of distilled water as required.

Four series of experiments were conducted. Groups of 20 mussels each were exposed to (a) copper: concentrations of 3.1 (control), 31.6, 56.2, 100, 178, and $316 \mu \mathrm{g}$ $1^{-1}$; (b) zinc: 11.0 (control), 31.6, 56.2, 100, 316, 562 and $3162 \mathrm{ug} \mathrm{l}^{-1}$; (c) lead: 6 (control), 100, 316, 562, 1000 and $1778 \mu \mathrm{g} \mathrm{l}^{-1}$; (c) cadmium: 0.7 (control), 31.6, 56.2, 100, 178 and $316 \mu \mathrm{g}^{-1}$. Dead mussels were removed daily (mussels were considered dead when the shell remained agape after tapping). After $21 \mathrm{~d}$, surviving mussels were rinsed in clean artificial seawater and stored frozen. Upon thawing, the 20 mussels in each experimental tank were divided into 4 groups of 5 (3 to 4 when mortalities had occurred). Tissues were removed from the shells with stainless steel equipment, pooled and homogenized by a non-contaminating polytron homogenizer. The byssus was discarded. Aliquots of $5 \mathrm{~g}$ of the homogenate were used to determine metal levels, after digestion with $25 \mathrm{ml}$ conc. nitric acid at $120^{\circ} \mathrm{C}$. The digest was analysed for $\mathrm{Cd}, \mathrm{Cu}, \mathrm{Pb}$ and $\mathrm{Cd}$ by flame atomic absorption spectrophotometry. A further $5 \mathrm{~g}$ aliquot of the homogenate was dried at $110^{\circ} \mathrm{C}$ and the dry: wet weight ratio determined. All metal concentrations are expressed in $\mu \mathrm{g} \mathrm{g}^{-1}$ dry tissue weight.

Experiment II: Rate of accumulation. Groups of 80 Perna viridis (35 to $45 \mathrm{~mm}$ shell length) were acclimatized in artificial seawater for $5 \mathrm{~d}$. All groups were exposed to various metal concentrations in 15 I artificial seawater in acid-washed $30 \mathrm{l}$ tanks. Metal concentratrion regimes were: $\mathrm{Cu}: 50$ and $100 \mu \mathrm{g} \mathrm{l^{-1 }}$; $\mathrm{Zn}: 100$ and $200 \mu \mathrm{g} \mathrm{l}^{-1}$; $\mathrm{Pb}: 100$ and $200 \mu \mathrm{g} \mathrm{l}^{-1} ; \mathrm{Cd}: 100$ and $200 \mathrm{mg} \mathrm{l}^{-1}$. Media were changed daily and metal levels monitored. Dead mussels were removed daily over the $7 \mathrm{~d}$ study; 15 live mussels were randomly sampled from experimental tanks at the end of Days 1 , 2, 5 and 7 and analysed for $\mathrm{Cd}, \mathrm{Cu}, \mathrm{Pb}$ and $\mathrm{Zn}$.

Experiment III: Mortality. Groups of 40 Perna viridis (shell length 30 to $40 \mathrm{~mm}$ ) were maintained in $5 \mathrm{l}$ artificial seawater in acid-washed $10 \mathrm{l}$ perspex tanks. Experimental concentrations were established on the basis of results of previous trial experiments: Cu: 3.1 (control), 100, 250,400, 630 and $1000 \mu \mathrm{g} \mathrm{l}^{-1}$; $\mathrm{Zn:} 11$ (control), 2500, 5000, 7500, 10000 and $12500 \mu \mathrm{g} \mathrm{l}^{-1}$; $\mathrm{Pb}: 6$ (control), 2500, 7500, 10000,12500 and 15000 $\mu \mathrm{g} \mathrm{I}^{-1}$; Cd: 0.7 (control), 250, 750, 1000, 1500 and 2500 $\mu \mathrm{g} \mathrm{l}^{-1}$. Media were changed daily. Mussels were disturbed as little as possible and inspected twice daily; dead ones being removed. Cumulative mortalities were recorded after $96 \mathrm{~h}$. Experiments were conducted between December 1986 and January 1987.

\section{RESULTS}

\section{Experiment I: Accumulation and regulation}

Table 1 gives a record of survivorship of mussels exposed to the increasing levels of $\mathrm{Cu}, \mathrm{Zn}, \mathrm{Pb}$ and $\mathrm{Cd}$ after $21 \mathrm{~d}$. Regression analysis of accumulated concentration against dose concentration indicate that $\mathrm{Cu}, \mathrm{Pb}$ and $\mathrm{Cd}$ are all accumulated in proportion to exposure levels at all external metal exposures (Fig. 1a, c, d). Data for the Cu control experiment $\left(3.1 \mu \mathrm{g} \mathrm{I}^{-1}\right)$, however, do not fall close to the line of best fit indicating

Table 1. Perna viridis. Percent surviving exposure for $21 \mathrm{~d}$ to various concentrations of $\mathrm{Cu}, \mathrm{Zn}, \mathrm{Pb}$, and $\mathrm{Cd}$ salts. Initial number per group $=20$. Dash: exposure not conducted

\begin{tabular}{|c|c|c|c|c|}
\hline Exposure levels $\left(\mu \mathrm{g}^{-1}\right)$ & $\mathrm{Cu}$ & $\mathrm{Zn}$ & $\mathrm{Pb}$ & $\mathrm{Cd}$ \\
\hline 0.7 & - & - & - & 100 (control) \\
\hline 3.1 & 100 (control) & & - & - \\
\hline 6.0 & - & - & 90 (control) & - \\
\hline 11.0 & - & 65 (control) & - & - \\
\hline 31.6 & 95 & 75 & - & 90 (control) \\
\hline 56.2 & 95 & 60 & - & 75 \\
\hline 100 & 95 & 75 & 60 & 75 \\
\hline 178 & 80 & - & - & 60 \\
\hline 316 & 0 & 80 & 75 & 60 \\
\hline 562 & - & 75 & 65 & - \\
\hline 1000 & - & - & 75 & - \\
\hline 1778 & - & - & 65 & - \\
\hline 3160 & - & 0 & - & - \\
\hline
\end{tabular}


that a considerable amount of $\mathrm{Cu}$ was present in the mussel body even at low ambient concentrations. This concentration may be equivalent to the baseline level for the metabolic requirements of the mussel (White \& Rainbow 1985).

There is no significant difference $(p>0.05)$ between the mean $\mathrm{Zn}$ body concentrations of controls and
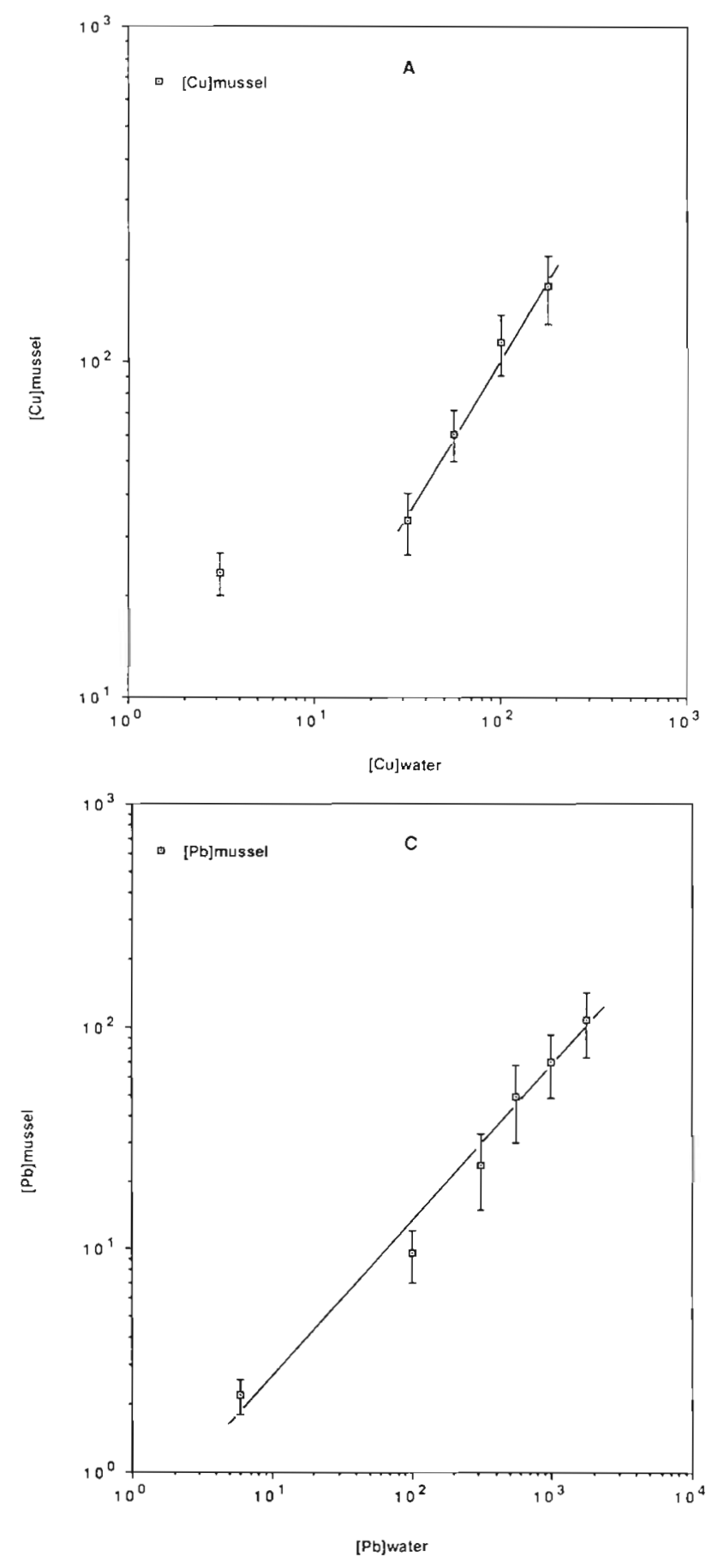

mussels exposed to $\mathrm{Zn}$ levels of up to $100 \mu \mathrm{g} \mathrm{l^{-1 }}$ after $21 \mathrm{~d}$ (Fig. 1b); these were significantly lower than those for higher exposure levels (316 and $562 \mu \mathrm{g} \mathrm{I}^{-1}$ ). This implies an ability of Perna viridis to maintain a constant body $\mathrm{Zn}$ concentration at ca $100 \mu \mathrm{g} \mathrm{g} \mathrm{g}^{-1}$ at exposures up to $100 \mathrm{\mu g} \mathrm{l}^{-1}$. At higher levels of dissolved $\mathrm{Zn}$, there is an increase in body $\mathrm{Zn}$ concentration which then
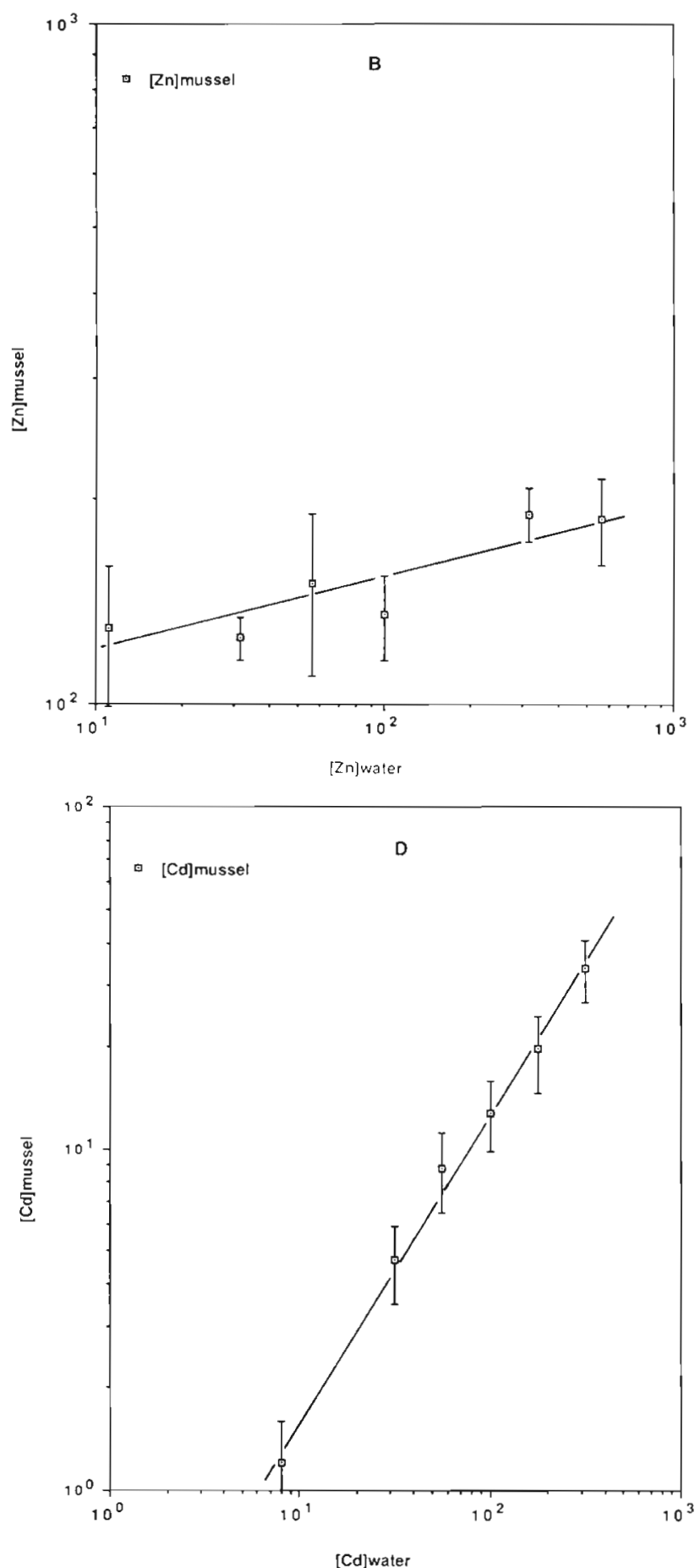

Fig. 1. Perna viridis. Mean body metal concentrations $\left(\mu \mathrm{g} \mathrm{g}{ }^{-1}\right.$ dry $\left.w t \pm S D\right)$ in individuals exposed to increasing concentrations of dissolved metals $\left(\mu \mathrm{g} \mathrm{l}^{-1}\right)$ for $21 \mathrm{~d}$ at $20^{\circ} \mathrm{C}$ (log-log plot). (A) Copper, (B) zinc, (C) lead, (D) cadmium 
reaches a plateau at around $250 \mu \mathrm{g} \mathrm{g}^{-1}$. The highest measured tissue concentration of dead mussels exposed to $3162 \mu \mathrm{g} \mathrm{l}^{-1}$ was only $250 \mu \mathrm{g} \mathrm{g}^{-1}$.

Tissue metal concentration as a function of the level of contamination in experimental media can be expressed in terms of concentration factor (CF), where

$\mathrm{CF}=\frac{\text { conc. in contaminated organisms }\left(\mu \mathrm{g} \mathrm{g}^{-1} \text { wet } \mathrm{wt}\right)}{\text { conc } \text { in contaminated media }\left(\mu \mathrm{g} \mathrm{l}^{-1}\right)}$

In the case of $\mathrm{Cu}, \mathrm{Pb}$ and $\mathrm{Cd}$, concentration factors showed an initial decrease with increasing metal concentrations in the experimental media, then rapidly reached constant values of 200, 10 and 25 for $\mathrm{Cu}, \mathrm{Pb}$ and $\mathrm{Cd}$ respectively (Table 2 ). In these instances, the increase in the levels of $\mathrm{Cu}_{1} \mathrm{~Pb}$ and $\mathrm{Cd}$ in the mussels therefore paralleled the increase of dissolved concentration of these metals in the experimental media. The decreasing trend did not stop for $\mathrm{Zn}$, however, implying that the body $\mathrm{Zn}$ concentration was independent of the ambient $\mathrm{Zn}$ level and remained almost constant.

\section{Experiment II: Rate of accumulation}

The pattern of net accumulation was similar for $\mathrm{Cu}$, $\mathrm{Pb}$ and $\mathrm{Cd}$ (Fig. 2a, b, d). These metals were continuously accumulated in the tissues of Perna viridis throughout exposure, and correlations of the regression lines $(p<0.01)$ indicate that accumulation is linear with time. Assuming a linear time course over the $7 \mathrm{~d}$ experiment, the rate of net accumulation was calculated to be 8.57 and $17.1 \mu \mathrm{g} \mathrm{g}^{-1} \mathrm{~d}^{-1}$ in 50 and $100 \mu \mathrm{g} \mathrm{l}^{-1}$ copper media respectively. Rates of uptake in $100 \mu \mathrm{g}$ $\mathrm{I}^{-1}$ and $200 \mu \mathrm{g} \mathrm{I}^{-1}$ contaminated media were estimated to be 1.96 and $3.62 \mu \mathrm{g} \mathrm{g}^{-1} \mathrm{~d}^{-1}$ for $\mathrm{Pb}$, and 0.62 and 1.13 $\mu \mathrm{g} \mathrm{g}^{-1} \mathrm{~d}^{-1}$ for $\mathrm{Cd}$. The $\mathrm{Cu}, \mathrm{Pb}$ and $\mathrm{Cd}$ concentrations in the organism increased with increases in the metal concentrations of the experimental media after a given time from the start of the experiment.

The pattern of $\mathrm{Zn}$ accumulation was different from that of the other 3 metals (Fig. 2b). Analysis of variance has shown that there is no significant difference between the $\mathrm{Zn}$ concentrations of the control mussels and those exposed to 100 and $200 \mu \mathrm{gn} \mathrm{l}^{-1}\left(\mathrm{~F}_{\mathrm{s}}=2.47, p\right.$ $>0.05$, d.f. $=2.33$ ). No significant correlation between body $\mathrm{Zn}$ concentration and time of exposure could be obtained. The $\mathrm{Zn}$ concentration of all mussels remained almost constant at around $100 \mu \mathrm{g} \mathrm{g}^{-1}$. Evidently Perna viridis can maintain a constant body $\mathrm{Zn}$ concentration at exposures up to $200 \mu \mathrm{g} \mathrm{I}^{-1}$ throughout the experimental period.

\section{Experiment III: Toxicity}

Results obtained from toxicity tests are expressed as $\mathrm{LC}_{50}$, i.e. the concentration of trace metals killing $50 \%$ of the mussels during the $96 \mathrm{~h}$ exposure period. The $\mathrm{LC}_{50}$ values were estimated by probit analysis and the results are summarized in Table 3. Metal toxicity in Perna viridis increases in the sequence $\mathrm{Pb}<\mathrm{Zn}<\mathrm{Cd}<\mathrm{Cu}$. The $\mathrm{LC}_{50} 96 \mathrm{~h}$ for $P$. viridis in $\mu \mathrm{g} \mathrm{l}^{-1}$ is 620 for $\mathrm{Cu}, 6090$ for $\mathrm{Zn}, 8820$ for $\mathrm{Pb}$, and 1570 for $\mathrm{Cd}$.

A visible sign of metal toxicity was an increase in mucous secretion by the treated mussels, resulting in media foaming. The frothing increased with increasing metal concentration. Another response of the mussels to metal exposure was sustained valve adduction, particularly at higher concentrations.

No deaths occured in the controls.

Table 2. Perna viridis. Concentration factors ${ }^{*}$ of surviving after exposure to various concentrations of $\mathrm{Cu}, \mathrm{Zn}, \mathrm{Pb}$ and $\mathrm{Cd}$ salts for $7 \mathrm{~d}$. Dash: no exeriment at this exposure level; NS = no survivors

\begin{tabular}{|c|c|c|c|c|}
\hline Exposure levels $\left(\mu \mathrm{g} \mathrm{l}^{-1}\right)$ & $\mathrm{Cu}$ & $\mathrm{Zn}$ & $\mathrm{Pb}$ & $\mathrm{Cd}$ \\
\hline 0.7 & - & - & - & 198 (control) \\
\hline 3.1 & 1508 (control) & - & - & - \\
\hline 6.0 & - & - & 66 (control) & - \\
\hline 11.0 & - & 2342 (control) & - & - \\
\hline 31.6 & 214 & 796 & - & 29 \\
\hline 56.2 & 220 & 592 & - & 31 \\
\hline 100 & 230 & 286 & 24 & 26 \\
\hline 178 & 186 & - & - & 24 \\
\hline 316 & NS & 122 & 14 & 23 \\
\hline 562 & - & 66 & 15 & - \\
\hline 1000 & - & - & 12 & - \\
\hline 1778 & - & - & 11 & - \\
\hline 3160 & - & NS & - & - \\
\hline \multicolumn{5}{|c|}{ - Concentration in mussel soft tissues in $\mathrm{kg} \mathrm{g}^{-1}$ wet wt } \\
\hline
\end{tabular}



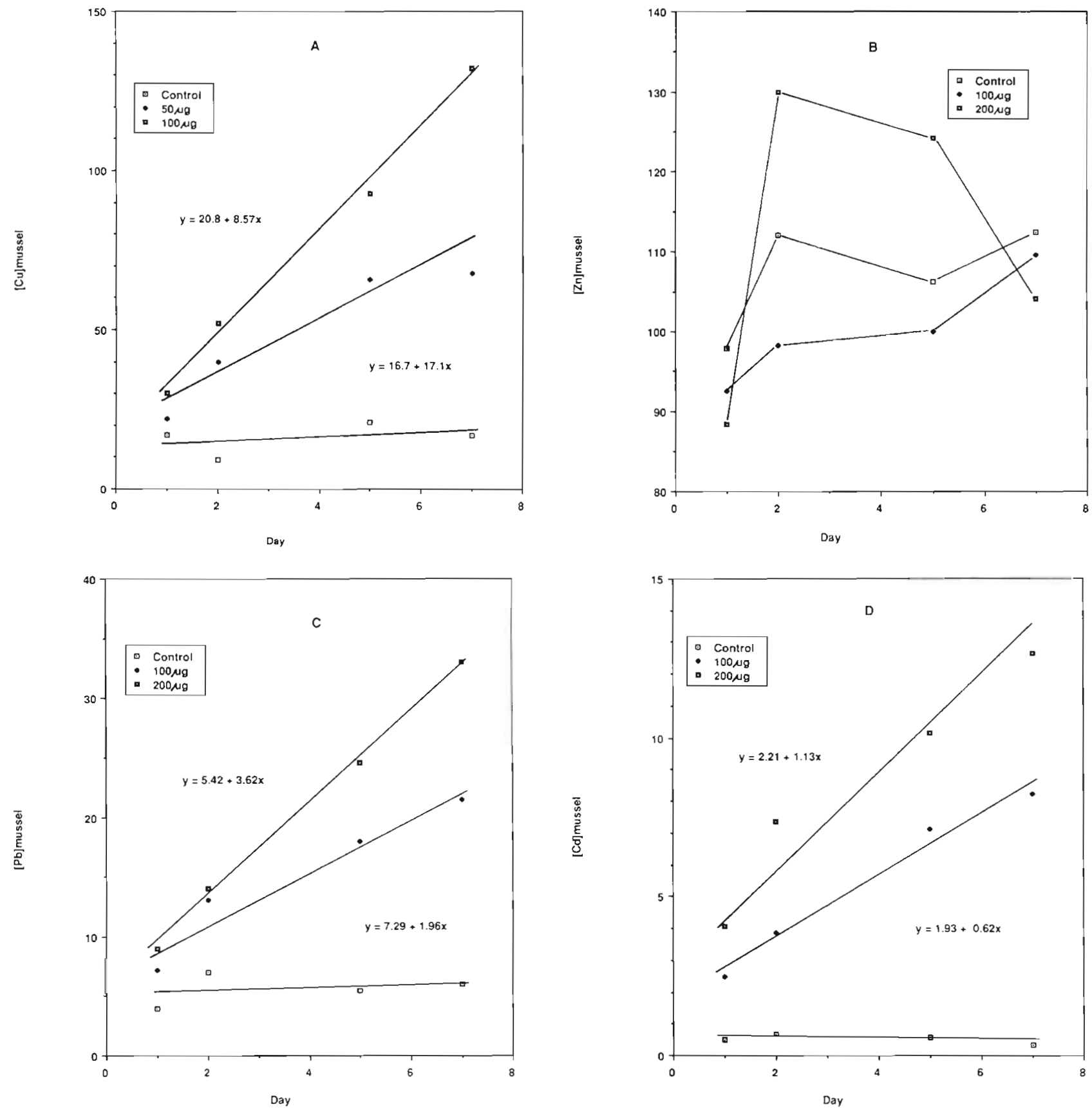

Fig. 2. Perna viridis. Mean metal uptake at different exposure concentrations with time. (A) Copper, (B) zinc, (C) lead, (D) cadmium

Table 3. Perna viridis. Probit equations and LC-50 (96 h) values for $\mathrm{Cu}, \mathrm{Zn}, \mathrm{Pb}$, and $\mathrm{Cd}$

\begin{tabular}{|c|c|c|c|c|}
\hline \multirow[t]{2}{*}{ Metal } & \multirow{2}{*}{$\begin{array}{l}\text { Probit regression equation } \\
(y=\text { probits, } x=\log \text { dose) }\end{array}$} & \multirow{2}{*}{$\begin{array}{c}96 \mathrm{~h} \mathrm{LC}-50 \\
\left(\mu \mathrm{g} \mathrm{l}^{-1}\right)\end{array}$} & \multicolumn{2}{|c|}{$95 \%$ fiducial limit } \\
\hline & & & lower & upper \\
\hline $\mathrm{Cu}$ & $y=2080 x-1060$ & 620 & 440 & 1010 \\
\hline $\mathrm{Zn}$ & $y=2840 x-7120$ & 6090 & 4320 & 8560 \\
\hline $\mathrm{Pb}$ & $y=2570 x-5990$ & 8820 & 4740 & 12610 \\
\hline $\mathrm{Cd}$ & $y=2210 x-2070$ & 1570 & 1280 & 1960 \\
\hline
\end{tabular}




\section{DISCUSSION}

In the present study a linear accumulation by Perna viridis of $\mathrm{Cu}, \mathrm{Pb}$ and $\mathrm{Cd}$ over a wide range of concentrations has been recorded. A similar accumulation pattern of mussels has been reported for Cu (D'Silva \& Kureishy 1978, Ritz et al, 1982), Pb (Schulz-Baldes 1974, Tan \& Lim 1984), and Cd (Poulsen et al. 1982, Ritz et al. 1982, Amiard-Triquet et al. 1986). The rate of accumulation of each metal is proportional to the level of contamination over $7 \mathrm{~d}$. $P$. viridis concentrated $\mathrm{Cu}$ $\mathrm{Pb}$ and $\mathrm{Cd}$ from experimental media up to 200,10 and 25 times respectively. These concentration factors remained almost constant over a wide contamination range, increases in body concentration of these metals paralleling increases in ambient dissolved metal concentrations.

Martin (1979) reported that in Mytilus edulis the lethal accumulation level was $59.9 \mu \mathrm{gl}^{-1}$ for $\mathrm{Cu}$ and the lethal time was $6 \mathrm{~d}$ for exposure concentrations higher than $100 \mu \mathrm{g} \mathrm{l}^{-1}$. The present study, however, has shown that Perna viridis can accumulate over $100 \mu \mathrm{g} \mathrm{g}^{-1} \mathrm{Cu}$ when exposed to $200 \mu \mathrm{g} \mathrm{I}^{-1}$ medium for $7 \mathrm{~d}$. Cu concentrations for in situ $P$. viridis can reach $300 \mu \mathrm{g} \mathrm{g}^{-1}$ (Phillips 1985). Since experimental mussels were collected from a fairly clean site according to Phillips (1985) and had been maintained in laboratory conditions for $60 \mathrm{~d}$, the argument put forward by Martin (1979) that tolerance was induced by adaptation cannot apply to $P$. viridis. Other factors such as temperature and salinity may also affect the toxicity of trace metals to mussels (McLusky et al. 1986). However, these experimental conditions are often not stated (e.g. Martin 1979). It is therefore not possible to make direct comparisons. Nevertheless, results of this study suggest that $P$. viridis can accumulate high levels of $\mathrm{Cu}$ as compared with other mussels (Eisler 1981). Since the maximum sublethal concentration accumulated under the experimental conditions $\left(178 \mu \mathrm{g} \mathrm{g}^{-1}\right)$ is not much lower than the concentration found in dead mussels exposed to $316 \mu \mathrm{g} \mathrm{l}^{-1}$ for $11 \mathrm{~d}\left(256 \mu \mathrm{g} \mathrm{g}^{-1}\right)$, the range between tolerable and lethal concentrations is narrow for $\mathrm{Cu}$. Mortality has presumably resulted from a failure to balance the rate of incorporation of $\mathrm{Cu}$ into detoxification pathways to the increased rate of uptake under high $\mathrm{Cu}$ exposure concentrations.

An ability to accumulate and tolerate high body concentrations of $\mathrm{Cu}, \mathrm{Pb}$ and $\mathrm{Cd}$ implies that Perna viridis possesses mechanisms that prevent interaction of the toxic metals with essential enzymes. Metal detoxification by marine invertebrates is reportedly achieved by employing physiological and biochemical processes (Simkiss 1981) which may, for example, include the production of physiologically inert granular deposits (Mason \& Nott 1981, Brown 1982) or the induction of metal-binding proteins such as metallothioneins (Cherian \& Goyer 1978, Roesijadi 1981). Viarengo et al. (1981) have demonstrated that $\mathrm{Cu}^{2+}$, when present in seawater at the sublethal concentration of $0.08 \mathrm{mg} \mathrm{l}^{-1}$, is able to induce, within $48 \mathrm{~h}$, the synthesis of $\mathrm{Cu}$-binding proteins having a molecular weight similar to that of the metallothioneins (12000) in the gills and mantle of Mytilus galloprovincialis. It is tentatively suggested that $\mathrm{Cu}$ accumulated from natural concentrations is stored bound to these high molecular weight proteins and thus detoxified (see Roesijadi 1981 for a review of the significance of metallothioneins in marine invertebrates).

The mechanism of immobilization and detoxification of $\mathrm{Pb}$ by Mytilus edulis has been described by SchulzBaldes (1977). He demonstrated that $\mathrm{Pb}$ is taken up in gills and viscera, distributed by the blood and finally stored as a phosphorus or sulphur-rich complex in membrane-bound vesicles (i.e. in intracellular storage sites) within the excretory cells of the kidney. He suggested that uptake into the cells occurs by pinocytosis. This immobilization of $\mathrm{Pb}$ in a chemically inert form outside the cytoplasm would be an internal detoxification process.

Similar detoxification mechanisms have been reported for Cd. Janssen \& Scholz (1979) suggested that $\mathrm{Cd}$ is concentrated in the midgut gland of Mytilus edulis. They showed that $\mathrm{Cd}$ is transported via the haemolymph, and that selective discrimination and accumulation occurs at the basement lamina of the digestive tubules. Within the tubules, $\mathrm{Cd}$ is immobilized in membrane-bound vesicles, which are finally released into the intestine and faeces.

The above mechanism may apply to Perna viridis, but this has not been investigated. The deposition of metals in membrane-bound cytoplasmic bodies, however, appears to be a general biological process which occurs in a variety of phyla (Fowler et al. 1981).

Results from Experiments 1 and 2 show that Perna viridis can regulate total body levels of $\mathrm{Zn}$ up to a threshold exposure level. A similar $Z n$ regulating ability has been recorded for decapod crustaceans (Bryan 1976. White \& Rainbow 1982, Rainbow 1985, 1988). Among molluscs, Haliotis tuberculata and Scrobicularia plana are able to regulate $\mathrm{Zn}$ body levels (Bryan et al. 1977, Bryan 1979). Little experimental data pertaining to $\mathrm{Zn}$ regulation in mussels is available. AmiardTriquet et al. (1986) have demonstrated the ability of Mytilus edulis to maintain a normal concentration in all groups of organs for $4 d_{i}$ in the visceral mass, and the 'remainder' (mantle, muscles, gonads) for $8 \mathrm{~d}$; and in the 'remainder' alone for up to $16 \mathrm{~d}$. But with higher doses and increasing exposure time, the regulatory mechanism seemed to be perturbed. Tissue $\mathrm{Zn}$ accumulation by $M$. edulis increased linearly when exposed 
Table 4. Acute toxicity of $\mathrm{Cu}, \mathrm{Zn}, \mathrm{Pb}$, and $\mathrm{Cd}$ to marine mussels

\begin{tabular}{|c|c|c|c|}
\hline Species & Metal & $\begin{array}{l}\text { LC- } 50 \text { in } \mu \mathrm{g} \mathrm{l}^{-1} \\
\text { (time) }\end{array}$ & Source \\
\hline \multirow[t]{3}{*}{ Perna viridis } & $\begin{array}{l}\mathrm{Cu} \\
\mathrm{Zn}\end{array}$ & $\begin{array}{r}140(48 h) \\
2310(48 h)\end{array}$ & D'Silva \& Kureishy (1978) \\
\hline & $\begin{array}{l}\mathrm{Pb} \\
\mathrm{Cd}\end{array}$ & $\begin{array}{l}4460(168 \mathrm{~h}) \\
1020(168 \mathrm{~h})\end{array}$ & Tan \& Lim (1984) \\
\hline & $\begin{array}{l}\mathrm{Cu} \\
\mathrm{Zn} \\
\mathrm{Pb} \\
\mathrm{Cd}\end{array}$ & $\begin{array}{r}620(96 \mathrm{~h}) \\
6090(96 \mathrm{~h}) \\
8820(96 \mathrm{~h}) \\
1570(96 \mathrm{~h})\end{array}$ & Present study \\
\hline Mytilus edulis & $\begin{array}{l}\mathrm{Cu} \\
\mathrm{Zn} \\
\mathrm{Cu}\end{array}$ & $\begin{array}{r}480(96 \mathrm{~h}) \\
>5000(96 \mathrm{~h}) \\
1550(96 \mathrm{~h})\end{array}$ & Amiard-Triquet et al. (1986) \\
\hline Mytilus edulis planulatus & $\begin{array}{l}\mathrm{Zn} \\
\mathrm{Cd}\end{array}$ & $\begin{array}{l}2500(96 \mathrm{~h}) \\
1620(96 \mathrm{~h})\end{array}$ & Ahsanullah (1976) \\
\hline
\end{tabular}

to $100-200 \mu \mathrm{g} \mathrm{Zn} 1^{-1}$ over 35 to 86 d (D'Silva \& Kureishy 1978, Ritz et al. 1982). Results of D'Silva \& Kureishy (1978) for $P$. viridis, however, reveal that the ratio between $\mathrm{Zn}$ concentration of the most contaminated mussels and the control $35 \mathrm{~d}$ exposure was less than 3. Field studies have shown that the levels of $\mathrm{Zn}$ in $M$. edulis, Trichomya hirsuta and Septifer bilocularis do not vary considerably between polluted and unpolluted areas (Phillips \& Yim 1981, Klumpp \& Burdon-Jones 1982, Lobel et al. 1982, Phillips 1985). Results of field studies on $P$. viridis (Chan in press) confirm these observations and thus corroborate the hypothesis that $\mathrm{Zn}$ is regulated by all mussels (Mytilacea) hitherto studied.

George \& Pirie (1980) have presented a metabolism scheme for $\mathrm{Zn}$ in Mytilus edulis. The metal is taken up by both gill and mantle (possibly as soluble $\mathrm{Zn}$ ), as well as the gut (possibly as particulates or mucus-bound). Zn from the gill and gut is transported via the haemolymph to the kidney where it is stored in membrane-bound granules which occupy about $20 \%$ of the kidney volume. These granules, which have a long half life, are eventually excreted in the urine (George 1983 , Roesijadi et al. 1984, Lobel 1986). It is possible that the half life of the $\mathrm{Zn}$-bound granules is much shorter for $P$. viridis resulting in the narrow range of tissue concentrations recorded.

In the present study $\mathrm{LC}-50$ s for $\mathrm{Cu}, \mathrm{Zn}$ and $\mathrm{Pb}$ are generally higher than values previously reported for marine mussels (Table 4), while data for $\mathrm{Cd}$ had a similar range. The reasons for these differences are not known but may be related to differences in age, size and condition of the test animal, and the test environment. Toxicity is also influenced not only by the intrinsic toxicity of the element, but also by its availability as determined by occurrence, complexa- tion of other chemical reactions and absorption potential. Bryan (1976) has listed a series of factors influencing toxicity of heavy metals in solution. These include: the dissolved form of the metal, the presence of other metals, factors influencing the physiology and behaviour of the organism. Environmental factors such as temperature and salinity may also affect the toxicity of metals to the organism (McLusky et al. 1986). Nevertheless, when sensitivities to metals ( $\mathrm{Cu}, \mathrm{Zn}, \mathrm{Pb}$, Cd) are compared (Table 4), a common sequence is obtained. Perna viridis is most sensitive to $\mathrm{Cu}$ and least senstitive to $\mathrm{Pb}$.

The present study confirms the ability of Perna viridis to accumulate dissolved $\mathrm{Cu}, \mathrm{Pb}$ and $\mathrm{Cd}$ in proportion to exposure levels. $P$. viridis is also efficient in regulation $\mathrm{Zn}$, but not $\mathrm{Cu}$ as reported for Mytilus edulis by Phillips (1976, 1980) and Amiard-Triquet et al. (1986). Difference between minimum and maximum values of $\mathrm{Zn}$ concentrations among experimentally contaminated and control mussels are of the same order of magnitude as those observed in wild populations of mussels resulting from spatial and temporal factors (Chan unpubl.). P. viridis, therefore, is of limited value as an indicator of Zn pollution.

Acknowledgements. I thank my supervisor Professor Brian Morton for his constructive criticism on this manuscript. I am also grateful to Dr P. S. Rainbow and Dr D. J. H. Phillips for invaluable advice. This work formed part of a thesis submitted to University of Hong Kong for the degree of Master of Philosophy

\section{LITERATURE CITED}

Ahsanullah, M. (1976). Acute toxicity of cadmium and zinc to seven invertebrate species from Western port, Victoria. Aust. J. mar Freshwat. Res. 27: 187-196 
Amiard-Triquet, C., Berthet, B., Metayer, C., Amiard, J. C. (1986). Contribution to the ecotoxicological study of cadmium, copper and zinc in the mussel Mytilus edulis. II. Experimental study. Mar. Biol. 92: 7-13

Bone, K. M., Hibbert, W D. (1979). Solvent extractions with ammonium pyrolidinedithion carbamate and 2,6dimethyl-4-heptanone for the determination of trace metals in effluents and natural waters. Analyt. chim. Acta 107: 219-229

Brown, B. E. (1982). The form and function of metal-containing 'granules' in invertebrate tissues. Biol. Rev. 57: $621-667$

Bryan, G. W. (1976). Heavy metal contamination in the sea. In: Johnston R. (ed.) Marine pollution. Academic Press, London, p. 185-302

Bryan, G. W. (1979). Bioaccumulation of marine pollutants. Phil. Trans. R. Soc. Lond. (B) 286: 483-505

Bryan, G. W. Potts, G. W., Forster, G. R. (1977). Heavy metals in the gastropod mollusc Haliotis tuberculata (L.) J. mar. biol. Ass. U. K. 57: 379-390

Bryan, G. W. Langston, W. J., Hummerstone, L. G. (1980). The use of biological indicators of heavy metal contamination in estuaries. Occ. Publ. mar biol. Ass. U. K. 1 1-73

Bryan, G. W., Langston, W. J., Hummerstone, L. G., Burt, G. R. (1985). A guide to the assessment of heavy metal contamination in estuaries using biological indicators. Occ. Publ. mar. biol. Ass. U. K. 4: 1-92

Chan, H. M. (in press). A survey of trace metals in Perna viridis (L.) (Bivalvia: Mytılacea) from the coastal waters of Hong Kong. Asian Mar. Biol.

Cherian, M. G., Goyer, R. A. (1978). Metallothioneins and their role in the metabolism and toxicity of metals. Life Sci. 23: $1-10$

D'Silva, C., Kureishy, T W. (1978). Experimental studies on the accumulation of copper and zinc in the green mussel. Mar. Pollut. Bull. 9: 187-190

Eisler, R. (1981). Trace metal concentrations in marine organisms. Pergamon Press, New York

Fowler, B. A., Carmichael, N. G., Squibb, K. S., Engel, D. W (1981). Factors affecting trace metal uptake and toxicity to estuarine organisms. II. Cellular mechanisms. In: Vernberg J., Calabrese A., Thurberg F. P., Vernberg W. B. (eds.) Biological monitoring of marine pollutants. Academic Press, New York, p. 145-163

George, S. G. (1983). Heavy metal detoxification in Mytilus edulis kidney - an in vitro study of $\mathrm{Cd}$ - and $\mathrm{Zn}$-binding to isolated tertiary lysosomes. Comp. Biochem. Physiol. 76C: $59-65$

George, S. G., Pirie, B. J S (1980). Metabolism of zinc in the mussel Mytilus edulis (L.): a combined ultrastructural and biochemical study. J. mar biol. Ass. U. K. 60: 575-590

Janssen. H. H. Scholz, N. (1979). Uptake and cellular distribution of cadmium in Mytilus edulis. Mar. Biol. 55: 133-141

Klumpp, D. W., Burdon-Jones, C. (1982). Investigation of the potential of bivalve mollusca as indicators of heavy metal levels in tropical manne waters. Aust. J. mar. Freshwat. Res. 33: 285-300

Kremling, K., Peterson, H. (1974). ADPC-MIBK extraction. system for the determination of copper and iron in $1 \mathrm{~cm}^{3}$ of sea water by flameless atomic-absorption spectrometry Analyt. Chim. Acta 70: 35-39

Lobel, P. B. (1986). Role of kidney in determining the whole soft tissue zinc concentration of individual mussels (Mytilus edulis). Mar Biol. 92: 355-359

Lobel, P. B., Mogie, P., Wright, D. A., Wu, B. L. (1982). Metal accumulation in four molluscs. Mar Pollut. Bull. 13 $170-174$
Martin, J. L. M. (1979). Schema of lethal action of copper on mussels. Bull. Environ. Contam. Toxicol. 21. 808-814

Mason, A. Z., Nott. J. A. (1981). The role of intracellular biomineralized granules in the regulation and detoxification of metals in gastropods with special reference to the marine prosobranch Littorina littorea. Aquat. Toxicol. 1: 239-256

McLusky, D. S., Bryant, V., Campbell, R. (1986). The effects of temperature \& salinity on the toxicity of heavy metals to marine \& estuarine invertebrates. Oceanogr. Mar Biol Ann. Rev. 24: 481-520

Phillips, D. J. H. (1976). The common mussel Mytilus edulis as an indicator of pollution by zinc, cadmium, lead and copper. I. Effects of environmental variables on uptake of metals. Mar Biol. 38: 59-69

Phillips, D. J. H. (1977). The use of biological indicator organisms to monitor trace metal pollution in marine and estuarine environments - a review. Environ. Pollut. 13: 281-217

Phillips, D. J. H. (1980). Quantitative aquatic biological indicators. Their use to monitor trace metal and organochlorine pollution. Applied Science Publ. Ltd, London

Phillips, D. J. H. (1985). Organochlorines and trace metals in green-lipped mussels $P$. viridis from Hong Kong waters: a test of indicator ability. Mar. Ecol. Prog. Ser 21:252-258

Phillips, D. J. H., Yim, W.-W. S. (1981). A comparative evaluation of oyster, mussels and sediments as indicators of trace metals in Hong Kong waters. Mar. Ecol. Prog. Ser. 6 285-293

Phillips, D. J. H., Segar, D. A. (1986). Use of bioindicators in monitoring conservative contaminants - programme design imperatives. Mar. Pollut. Bull. 17: 10-17

Poulsen, E., Riisgard, H. U., Mohlenberg, F. (1982). Accumulation of cadmium and bioenergetics in the mussel Mytilus edulis. Mar. Biol. 68: 25-29

Prosi, F. (1979). Heavy metals in aquatic organisms. In: Forstner, U., Wittmann, T W. T (eds.) Metal pollution in the aquatic environment. Springer, Berlin, p. 271-323

Rainbow, P. S. (1985). Accumulation of $\mathrm{Zn}, \mathrm{Cu}$ and $\mathrm{Cd}$ by crabs and barnacles. Estuar coast. Shelf Sci. 21: 669-686

Rainbow, P. S. (1988). The significance of trace metal concentrations in decapods. Symp. Zool. Soc. Lond. 59: 291-313

Ritz, D. A., Swain, R., Elliott, N. G. (1982). Use of the mussel Mytilus edulis plamulatus (Lamarck) in monitoring heavy metal levels in seawater Aust. J. mar Freshwat. Res. 33: $491-506$

Roesijâdi, G. (1.981). The significance of low molecular weight metallothionein-like proteins in marine invertebrates: current status. Mar. environ. Res. 4: 167-179

Roesijadi, G., Young, J. S., Drum, A. S., Gurtisen, J. M. (1984). Behaviour of trace metals in Mytilus edulis during a reciprocal transplant field experiment. Mar. Ecol. Prog. Ser. 18: $155-170$

Schulz-Blades, M. (1974). Lead uptake from sea water and food and lead loss in the common mussel Mytilus edulis Mar. Biol. 25: 177-193

Schulz-Blades, M. (1977). Lead transport in the common mussel Mytilus edulis. In: McLusky, D. S., Berry, A. J (eds.) Physiology and behaviour of marine organisms. Pergamon Press, Oxford, p. 211-218

Simkiss, K. (1981). Cellular discrmmation processes in metal accumulating cells. J. exp. Biol. 94: 317-327

Tan, W H. Lim, L. H. (1984). The tolerance to and uptake of lead in the green mussel. Perna viridis (L). Aquaculture 42 $317-332$

White, S. L., Rainbow, P. S. (1982). Regulation and accumula- 
tion of copper, zinc and cadmium by the shrimp Palaemon elegans. Mar Ecol. Prog. Ser. 8: 95-101

White, S. L., Rainbow, P. S. (1985). On the metabolic requirements for copper and zinc in molluscs and curstaceans. Mar. environ. Res. 16: 215-229
Viarengo, A., Pertica, M., Mancinelli, G., Palmero, S., Zanicchi, G., Orunesu, M. (1981). Synthesis of Cu-binding proteins in different tissues of mussels exposed to the metal. Mar Pollut. Bull. 12: 347-350

This article was presented by Dr G. W. Bryan; it was accepted for printing on August 1, 1988 